Volume 1 Nomor 2 September 2019, Halaman 147 - 161

\title{
Pendampingan Budidaya Sayuran Sistem Hidroponik pada Kawasan Rumah Pangan Lestari (KRPL) Pengurus Cabang Bhayangkari Indramayu
}

\author{
Teguh Iman Santoso ${ }^{1}$, Karto $^{2}$ \\ teguhimans@unwir.ac.id ${ }^{1}$, kartofp@unwir.ac.id ${ }^{2}$ \\ Program Studi Agribisnis Universitas Wiralodra
}

\begin{abstract}
Abstrak
Tujuan dari kegiatan pengembangan Kawasan Rumah Pangan Lestari (KRPL) adalah memberdayakan rumah tangga dan masyarakat dalam penyediaan sumber pangan dan gizi melalui optimalisasi pemanfaatan pekarangan dan lahan sekitar tempat tinggal; meningkatkan kesadaran, peran, dan partisipasi masyarakat dalam mewujudkan pola konsumsi pangan yang beragam, bergizi seimbang dan aman. Upaya yang dilakukan adalah dengan mengembangkan kawasan Rumah Pangan Lestari (KRPL) di lingkungan rumah. Salah satu kegiatan dari kegiatan yang dilakukan dalam rangka mengembangkan KRPL adalah kegiatan pelatihan pengembangan budidaya sayuran dengan sistem hidroponik. Pelatihan dan pengembangan dudidaya tanaman dengan sistem hidroponik yang telah dilaksanakan oleh pengurus Bhayangkara Cabang Indramayu bekerjasama dengan Fakultas Pertanian Universitas Wiralodra. Setelah dilakukan pelatihan, peserta pelatihan memahami dan mempunyai keterampilan dalam membudidayakan sayuran dengan sistem hidroponik dengan berbagai metode yaitu wick system, NFT Sistem (Nutrient Film Technique) dan DFT Sistem (Deep Flow Technique); setelah dilakukan pelatihan memahami penanganan sayuran setelah panen dan memahami memahami bagaimana strategi yang harus dilakuakan dalam memasaran sayuran sistem hidroponik.
\end{abstract}

Kata Kunci: wick system, nutrient film technique, deep flow technique, hidroponik

\begin{abstract}
Abtract
The purpose of the activities of developing Sustainable Food Home Areas is to empower households and communities in providing food and nutrition sources through optimizing the use of the yard and land around the residence; increase awareness, role and community participation in realizing diverse, consumption-balanced and safe food consumption patterns. Efforts are being made to develop a sustainable food home area in the home environment. One of the activities carried out in the framework of developing the sustainable food home areas is a training activity on developing vegetable cultivation with a hydroponic system. Training and development of plant cultivation with a hydroponic system that has been carried out by the board of management of Bhayangkara Branch of Indramayu in collaboration with the Faculty of Agriculture, University of Wiralodra. After the training was conducted, the trainees understood and had skills in growing vegetables with a hydroponic system with various methods, namely wick system, NFT System (Nutrient Film Technique) and DFT System (Deep Flow Technique); after the training, understanding the handling of vegetables after harvest and understanding how to market the vegetables hydroponic system.
\end{abstract}

Keywords : wick system, nutrient film technique, deep flow technique, hydroponics 


\section{A. Pendahuluan}

Pemenuhan kebutuhan pangan merupakan suatu keharusan karena pangan merupakan salah satu kebutuhan dasar manusia. Menurut Undang-undang Nomor 18 Tahun 2012 tentang pangan, bahwa pangan adalah segala sesuatu yang berasal dari sumber hayati produk pertanian, perkebunan, kehutanan, perikanan, peternakan, perairan, danair,baik yang diolah maupun tidak diolah yang diperuntukkan sebagai makanan atau minuman bagi konsumsi manusia, termasuk bahan tambahan pangan, bahan baku pangan, dan bahan lainnya yang digunakan dalam proses penyiapan, pengolahan, dan/atau pembuatan makananatau minuman.

Selanjutnya pada Undang-undang tentang pangan tersebut tersebut dinyatakan bahwa bahwa pangan merupakan kebutuhan dasar manusia yang paling utama dan pemenuhannya merupakan bagian dari hak asasi manusia yang dijamin di dalam Undang-Undang Dasar Negara Republik Indonesia Tahun 1945 sebagai komponen dasar untuk mewujudkan sumber daya manusia yang berkualitas. Berdasarkan Undang-undang tersebut bahwa negara berkewajiban mewujudkan ketersediaan, keterjangkauan, dan pemenuhan konsumsi Pangan yang cukup, aman, bermutu, dan bergizi seimbang, baik pada tingkat nasional maupun daerah hingga perseorangan secara merata di seluruh wilayah Negara Kesatuan Republik Indonesia sepanjang waktu dengan memanfaatkan sumber daya, kelembagaan, dan budaya lokal.

Berdasarkan Undang-undang Nomor 18 tahun 2012 dinyatakan bahwa Pemenuhan pangan tidak hanya sekedar memenuhi kuantitas pangan tetapi juga kualitasnya. Penjabaran dari Undang-Undang Pangan tersebut telah diterbitkan Peraturan Pemerintah Nomor 17 Tahun 2015 tentang Ketahanan Pangan dan Gizi dimana dalam Pasal 26 disebutkan bahwa upaya penganekaragaman pangan salah satunya dilakukan melalui pemanfaatan lahan pekarangan.

Badan Ketahanan Pangan melalui Pusat Penganekaragaman Konsumsi dan Keamanan Pangan pada tahun 2018 meluncurkan Konsep Kawasan Rumah Pangan Lestari (KRPL), dalam rangka mempercepat penganekaragaman pangan dan memperkuat ketahanan pangan masyarakat, dengan adanya anjuran pemanfaatan pekarangan sangatlah tepat untuk memenuhi pangan dan gizi keluarga, mengingat selama ini pekarangan dan lahan disekitar lainnya belum dimanfaatkan secara optimal. Padahal lahan tersebut memiliki potensi untuk dikembangkan sebagai penghasil pangan, dalam memperbaiki gizi keluarga sekaligus meningkatkan pendapatan keluarga. Manfaatnya sangat besar, terutama bagi masyarakat golongan ekonomi lemah. Untuk itu Pemerintah telah menganjurkan agar memanfaatkan setiap jengkal tanah termasuk lahan tidur, galengan, maupun tanah kosong yang tidak produktif (Kementerian Pertanian Republik Indonesia Indonesia, 2018).

Melalui kegiatan ini diharapkan dapat meningkatkan kualitas konsumsi pangan masyarakat untuk membentuk pola konsumsi pangan yang baik. Kegiatan KRPL juga dilaksanakan dalam rangka mendukung program pemerintah untuk penurunan kemiskinan melalui kegiatan padat karya, penanganan daerah stunting, serta penanganan daerah rentan rawan pangan. Untuk mempercepat akselerasi gerakan pemanfaatan pekarangan melalui konsep KRPL, perlu dijalin kerja sama kemitraan dengan pihak swasta, antara lain berupa Corporate Social Responsibility 
(CSR)/Program Kemitraan dan Bina Lingkungan (PKBL). Kerjasama tersebut dapat dilakukan baik bidang pangan maupun bidang lainnya seperti pendidikan dengan sosialisasi kepada anak usia dini atau masyarakat lainnya (Kementerian Pertanian Republik Indonesia Indonesia, 2018).

Pelaksanaan kegiatan KRPL perlu dilakukan secara terintegrasi dengan kegiatan lainnya, baik dalam pelaksanaan maupun pembiayaannya. Tujuan dari kegiatan KRPL adalah memberdayakan rumah tangga dan masyarakat dalam penyediaan sumber pangan dan gizi melalui optimalisasi pemanfaatan pekarangan dan lahan sekitar tempat tinggal; meningkatkan kesadaran, peran, dan partisipasi masyarakat dalam mewujudkan pola konsumsi pangan yang beragam, bergizi seimbang dan aman (Kementerian Pertanian Republik Indonesia Indonesia, 2018).

Sebagai organisasi, pengurus cabang Bhayangkari Indramayu berupaya menganjurkan gaya hidup sehat dengan pola gizi seimbang sesuai dengan Program "GERMAS" (Gerakan Masyarakat Sehat) sebagai upaya pencegahan terhadap gangguan kesehatan keluarga. Upaya yang dilakukan adalah dengan mengembangkan kawasan Rumah Pangan Lestari (KRPL) di lingkungan rumah. Salah satu kegiatan dari kegiatan yang dilakukan dalam rangka mengembangkan KRPL adalah kegiatan pengembangan budidaya sayuran dengan sistem hidroponik.

Budidaya tanaman dengan sistem hidroponik adalah metode bercocok tanam dengan memanfaatkan air yang dipercaya dengan unsur hara (nutrisi) untuk pertumbuhan dan perkembangan tanaman. Sistem tanam hidroponik ini sangat cocok di aplikasikan di lahan kecil dan sifatnya lebih ramah lingkungan, sehingga menarik minat masyarakat untuk bercocock tanam (Rahmat, 2016).

Terdapat beberapa keistimewaan sayuran yang dibudidayakan dengan sistem hidroponik, yaitu simple (mudah) dan harganya lebih mahal dari harga sayuran biasa selain itu budidaya tanaman dengan sistem hidroponik tidak memerlukan lahan yang luas sehingga dapat diterapkan di lingkungan perumahan. Pengembangan budidaya sayuran dengan sistem hidroponik di KRPL Bhayangkari Cabang Indramayu, selain untuk memenuhi kebutuhan gizi keluarga, juga dapat meningkatkan pendapatan.

Berdasarkan hal tersebut maka dilakukan kerjasama antara Bhayangkari Cabang Indramayu dengan Fakultas Pertanian Universitas Wiralodra Indramayu dengan melaksanakan kegiatan pelatihan dan pendampingan. Tujuan dari kegiatan tersebut adalah untuk memberikan pengetahuan dan keterampilan ibu-ibu pengurus Bhayangkari Cabang Indramayu tentang budi daya tanaman dengan sistem hidroponik.

\section{B. Metode}

Metode yang digunakan dalam kegiatan pelatihan dan pengembangan budidaya sayuran dengan sistem hidroponik pada Kawasan Rumah Pangan Lestari (KRPL) Bhayangkari Cabang Indramayu adalah dengan melakukan pelatihan pendampingan produk sampai produk tersebut dipasarkan. Pelatihan yang dilakukan terdiri dari pelatihan tingkat dasar, lanjutan. 


\section{Pelatihan Tingkat Dasar}

Pelatihan tingkat dasar dilaksanakan pada tanggal 21 Februari 2019, materi yang diberikan adalah berupa pengenalan dasar dasar sistem budidaya tanaman dengan sistem hidroponik, yang terdiri dari pengenalan media tanam, benih, nutrisi dan perangkat/alat yang digunahan untuk budidaya sistem hidroponik. Adapun sistem budidaya hidroponik yang digunakan adalah sitem wick sytem yang merupakan sistem yang paling sederhana. Sistem ini merupakan sistem yang paling mudah karena merupakan sistem yang pasif karena tidak ada bagian yang bergerak baik nutrisi maupun mesin. Larutan nutrisi hidroponik diserap oleh tumbuhan melalui media sumbu yang berupa kain flannel maupun bahan lainya yang dapat menyerap air.

Alat dan bahan yang digunakan untuk wick system ini adalah tersedia di sekitar rumah, bahkan beberapa alat yang digunakan merupakan peralatan yang sudah tidak terpakai yang merupakan sampah. Berikut ini adalah alat dan bahan yang digunakan :

1. Bak nutrisi hidroponik (Ember bekas, Styrofoam bekas buah, botol bekas air mineral, kaleng bekas cat dll).

2. Media tanam (rockwool, arang sekam, kapas, cocofit dll)

3. Net pot/gelas pelastik

4. Kain flannel atau bahan lainnya yang dapat menyerap air

5. Nutrisi hidroponik (AB Mix)

6. Air

7. Benih

8. Alat pelubang Styrofoam

9. Cutter/pisau pemotong

10. Gunting

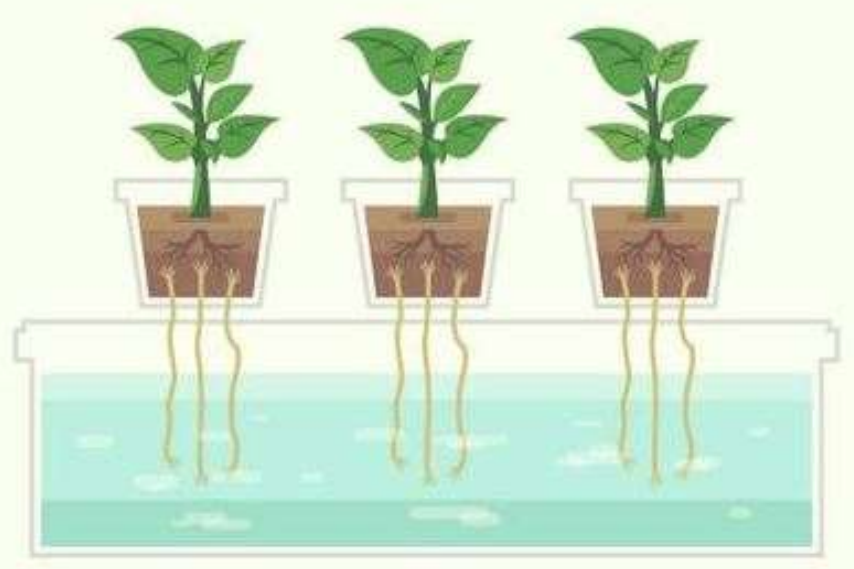

Gambar 1. Starter Kit Hidroponik Wick System

Sumber : https://id.pinterest.com/pin/591378994788675315/

Kegiatan pelatihan tingkat dasar yang dilaksanakan diharapkan memberikan pengetahuan dan keterampilan dasar berkaitan dengan budidaya tanaman sistem hidroponik. Beberapa keterampilan yang diperoleh para peserta pelatihan pada tingkat dasar ini adalah kemampuan peserta untuk membuat sendiri perangkat yang digunakan 
dalam budidaya dengan sistem hidroponik dengan memanfaatkan barang bekas seperti botol air mineral, ember bekas maupun Styrofoam bekas buah.

\section{Pelatihan Lanjutan}

Kegiatan pelatihan tingkat lanjutan merupakan pelatihan yang dilakukan untuk memberikan pengenalan dan keterampilan budidaya sistem hidroponik dengan metode yang lebih rumit dibandingkan dengan metode wick system. Sistem hidroponik yang diperkenalkan pada pelatihan tingkat lanjutan ini adalah:

a. NFT Sistem (Nutrient Film Technique)

NFT Sistem merupakan sistem hidroponik yang bekerja dengan cara membagikan air nutrisi pada tanaman melalui aliran air yang tipis. Nutrisi dibuat terus-menerus bersirkulasi menggunakan pompa tanpa menggunakan timer. Pada bagian akar tanaman tidak semua terendam di dalam air nutrisi, sehingga akar yang tidak terendam air tersebut diharapkan mampu mengambil oksigen untuk pertumbuhan tanamannya

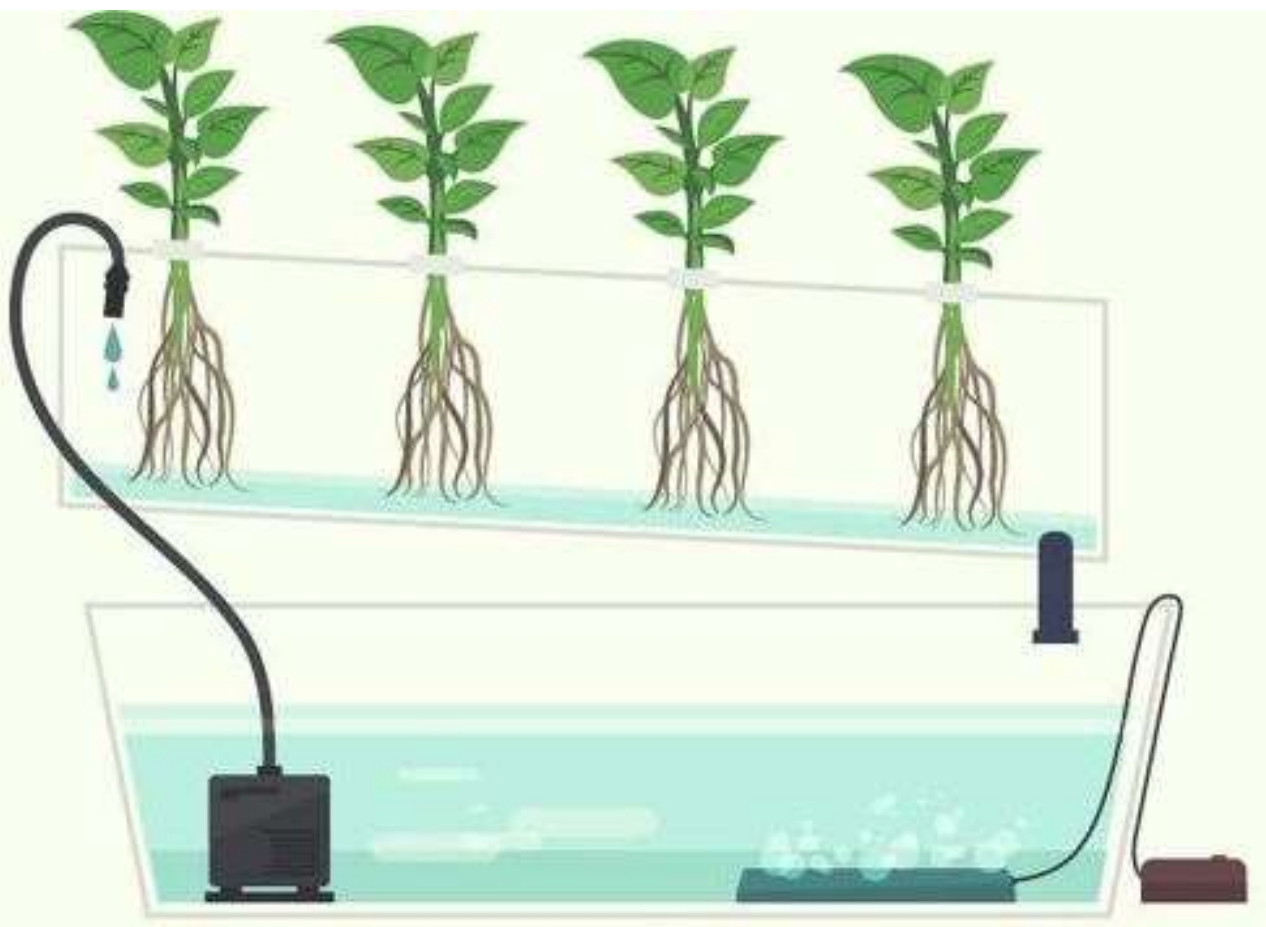

Gambar 2. NTF System

Sumber : https://id.pinterest.com/pin/591378994788675315/

b. DFT Sistem (Deep Flow Technique)

DFT sistem adalah cara menanam tanaman dengan mensirkulasikan larutan nutrisi tanaman secara terus-menerus selama 24 jam pada rangkaian aliran tertutup. Larutan nutrisi tanaman di dalam tangki dipompa oleh pompa air menuju bak penanaman 
melalui jaringan irigasi pipa, kemudian larutan nutrisi tanaman di dalam bak penanaman dialirkan kembali menuju tangki.

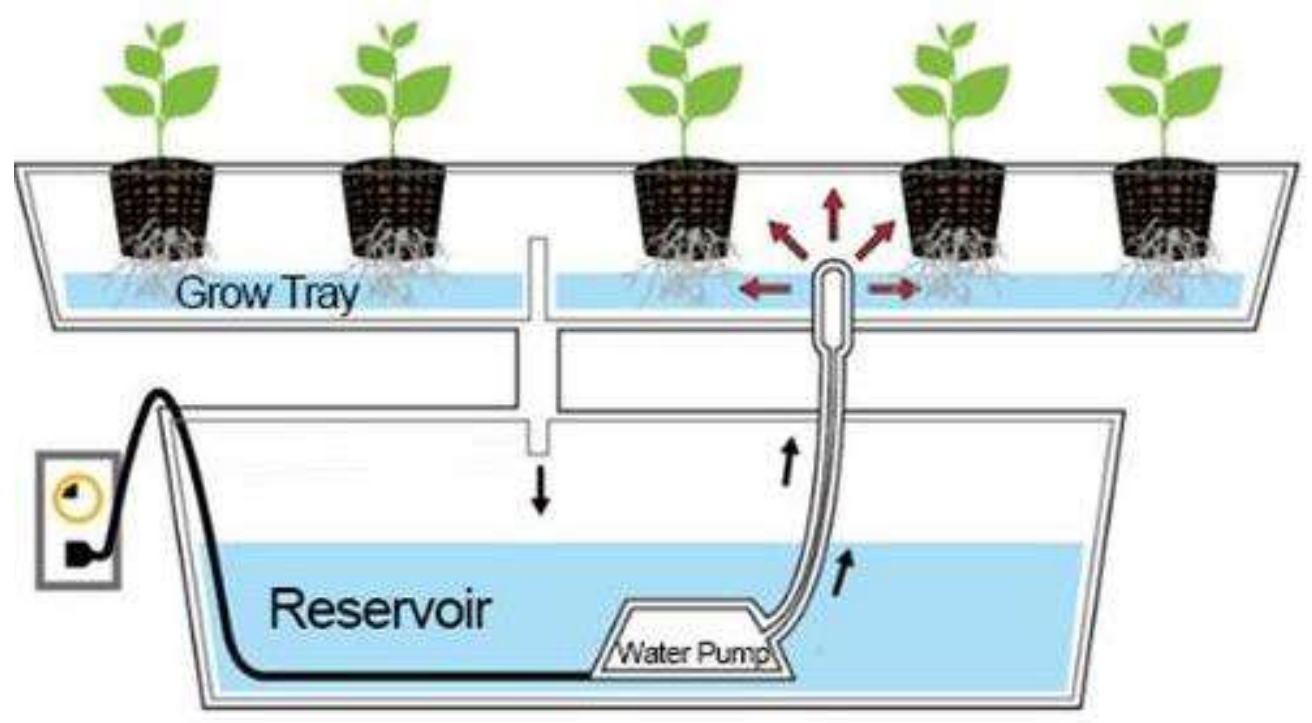

Gambar 3. DFT Sistem

Sumber : http://www.yoonhidroponik.web.id/2017/07/hydroponics-deep-flowtechnique-system.html

Pada pelatihan tingkat lanjutan ini peserta pelatihan dianggap sudah memahami dan mampu menerapkan materi pelatihan di tingkat dasar. Pelatihan tingkat lanjutan ini memerlukan instalasi hidroponik NTF, dan DFT. Pengurus Bhayangkara Cabang Indramayu menyediakan instalasi hidroponik yang digunakan pada pelatihan tersebut. Adapun instalasi hidroponik yang digunakan untuk pelatihan dapat dilihat pada Gambar 4. dan 5 berikut ini :

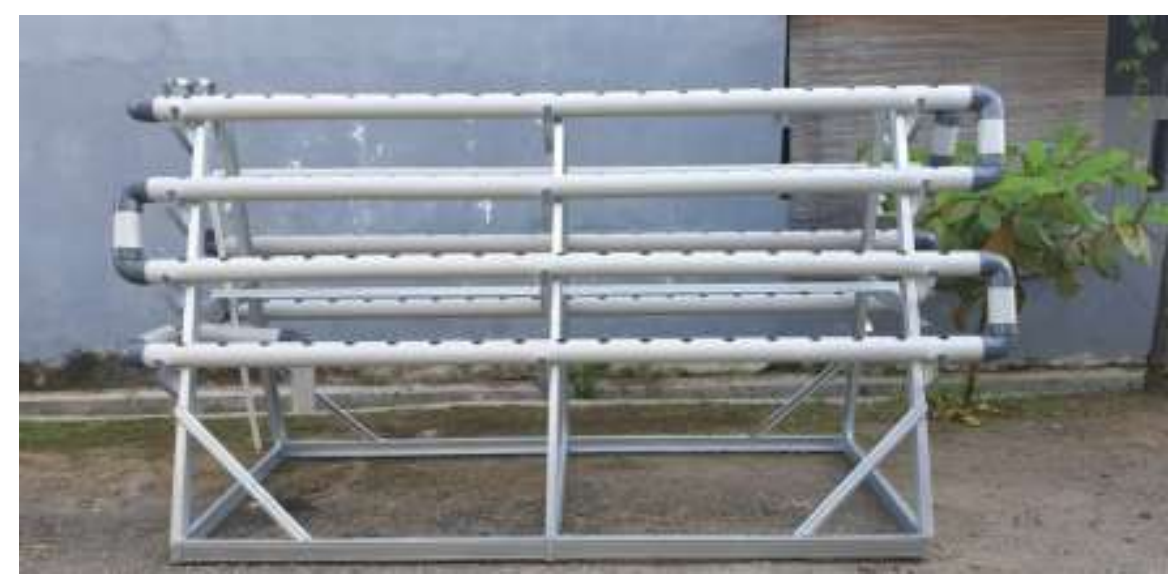

Gambar 4. Instalasi Hidroponik NTF 


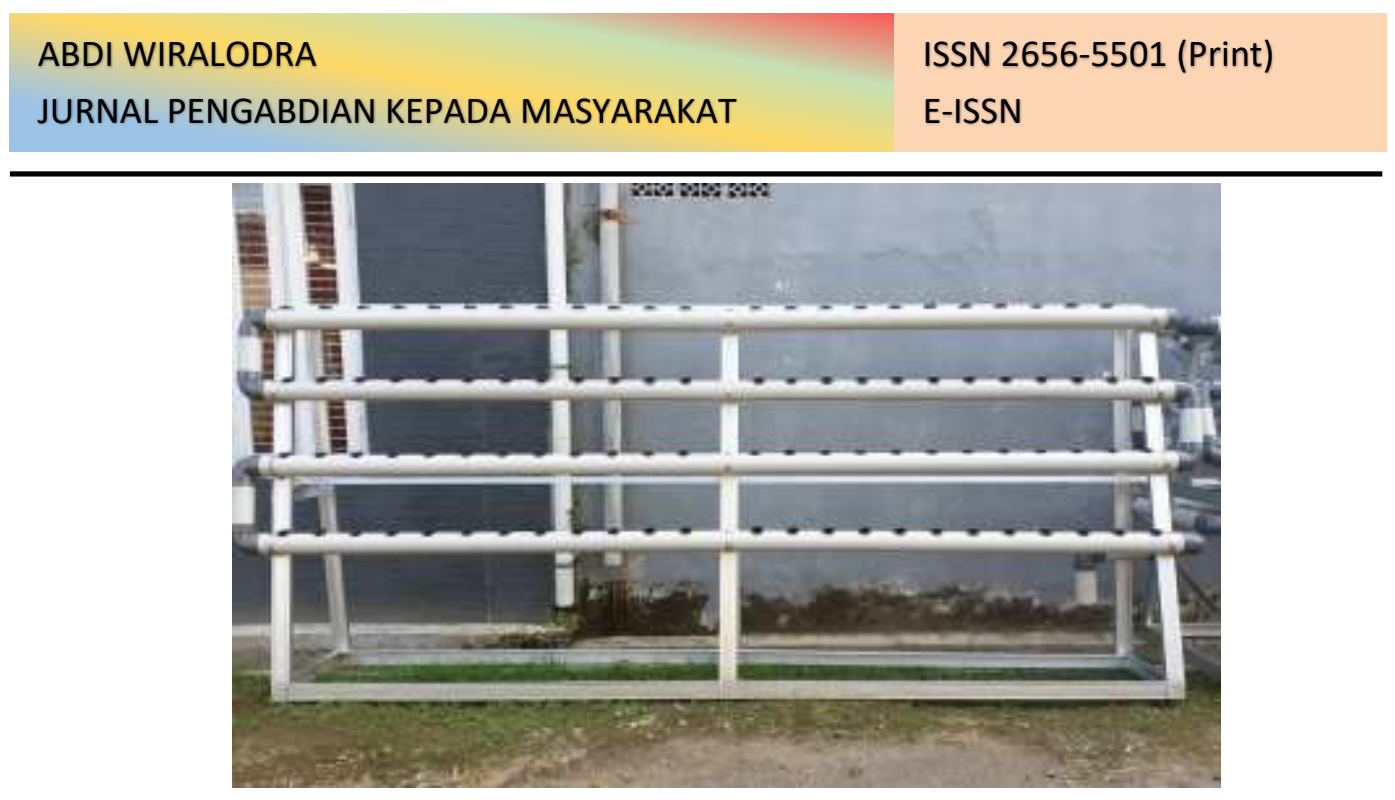

Gambar 5. Instalasi Hidroponik DFT

Selain pemahaman tentang sistem hidroponik lanjutan seperti sistem NTF dan DFT, pada pelatihan tersebut disampaikan materi yang berkaitan dengan ilmu nutrisi hidroponik yang terdiri dari pemahaman unsur-unsur hara nutrisi maupun pemahaman mengenai kepekatan nutrisi yang biasa disebut electro conductivity serta pemahaman mengenai derajat keasaman larutan nutrisi atau lebih dikenal adalah $\mathrm{pH}$ (potencial of hydrogen).

Kegiatan pelatihan ini adalah di Kawasan Rumah Pangan Lestari (KRPL) Bhayangkari Cabang Indramayu yang berlokasi di Asrama Polisi, Kelurahan Kepandean, Kabupaten Indramayu. Peserta pelatihan budidaya tanaman sayuran dengan sistem hidroponik ini berjumlah 15 orang yang terdiri dari ibu-ibu anggota Bhayangkari Cabang Indramayu.

Waktu pelatihan untuk tahap lanjutan ini dilaksanakan dengan beberapa tahapan dapat dilihat pada tabel berikut ini berikut :

Tabel 1. Tahapan Kegiatan Pelatihan Budidaya Sayuran Hidroponik dengan Metode NTF dan DFT.

\begin{tabular}{|c|c|c|}
\hline No & Materi Pelatihan & Waktu \\
\hline 1. & $\begin{array}{l}\text { Pelatihan persemaian dan meracik Nutrisi serta } \\
\text { penanaman serta pemeliharaan dengan sistem NTF } \\
\text { dan DFT }\end{array}$ & 2 Maret 2019 \\
\hline 2. & Pelatihan pasca panen & 4 April 2019 \\
\hline 3. & $\begin{array}{l}\text { Pelatihan penanaman dengan berbagai tanaman } \\
\text { sayuran yang berbeda serta pemahaman tentang } \\
\text { kepekatan (EC) serta derajat keasaman nutrisi } \mathrm{pH} \text { ) }\end{array}$ & 26 Juni 2019 \\
\hline 4. & $\begin{array}{l}\text { Pemahaman tentang ilmu pemasaran sayuran } \\
\text { hidroponik }\end{array}$ & 3 Agustus 2019 \\
\hline
\end{tabular}




\section{Hasil dan Pembahasan}

Kegiatan pelatihan budidaya sayuran dengan sistem hidroponik di Kawasan Rumah Pangan Lestari (KRPL) Bhayangkari Cabang Indramayu yang telah dilakukan dari tanggal 2 Maret s.d. 3 Agustus 2019 merupakan upaya untuk melaksanakan anjurkan gaya hidup sehat dengan pola gizi seimbang sesuai dengan Program "GERMAS" (Gerakan Masyarakat Sehat) sebagai upaya pencegahan terhadap gangguan kesehatan keluarga. Pelatihan ditujukan untuk menyampaikan pengetahuan, sikap dan meningkatkan keterampilan anggota Bhayangkari Cabang Indramayu tentang budidaya dengan sistem hidroponik.

Sebagai kegiatan penyampaian inovasi baru, penyampaian informasi tentang budidaya sayuran dengan sistem hidroponik haruslah didukung dengan commitment dari calon adopter. Oleh karena itu diperlukan informasi yang memadai. Berkaitan dengan proses adopsi tersebut terdapat hal yang harus diperhatikan oleh calon adopter: 1) adanya pihak lain yang telah melaksanakan adopsi inovasi dengan berhasil dan sukses; 2) adanya suatu proses adopsi inovasi yang berjalan secara sistematis, sehingga dapat diikuti dengan mudah oleh calon adopter; 3) adanya hasil adopsi inovasi yang sukses yang telah memberikan keuntungan, sehingga informasi yang berkaitan dengan inovasi baru akan memberikan dorongan kepada calon adopter untuk melaksanakan adopsi inovasi baru (Soekartawi,2005).

Berkaitan dengan hal tersebut di atas pelatihan yang dilakukan bukan hanya berkaitan dengan Teknik budidaya sayuran dengan sistem hidroponik saja, akan tetapi dengan menyampaikan beberapa kisah sukses budidaya dengan sistem hidroponik. Tujuannya penyampaian kisah suskses adalah agar peserta pelatihan (calon adopter) termotivasi untuk menerapkannya.

Pelatihan budidaya sistem hidroponik yang telah dilakukan telah berhasil meningkatkan minat peserta pelatihan, hal tersebut terlihat dengan keseriusan peserta pelatihan dan banyak diantara mereka yang bertanya berkaitan dengan materi pelatihan yang disampaikan. Keseriusan peserta pelatihan tersebut dapat di lihat pada pelatihan tingkat dasar maupun pelatihan di tingkat lanjutan.

Apabila dilihat dari capaian yang ingin di peroleh dalam pelatihan tingkat dasar adalah kemampuan peserta dalam mengenal media tanam, benih, nutrisi hidroponik dan peralatan yang digunakan dalam budidaya sayuran dengan sistem hidroponik. Selain itu peserta pelatihan mampu membuat sendiri perangkat sederhana yang digunakan dalam budidaya dengan sistem hidroponik dengan memanfaatkan barang bekas seperti botol air mineral, ember bekas maupun Styrofoam bekas buah. Berikut ini adalah kemampuan dasar yang diperoleh peserta pelatihan : 

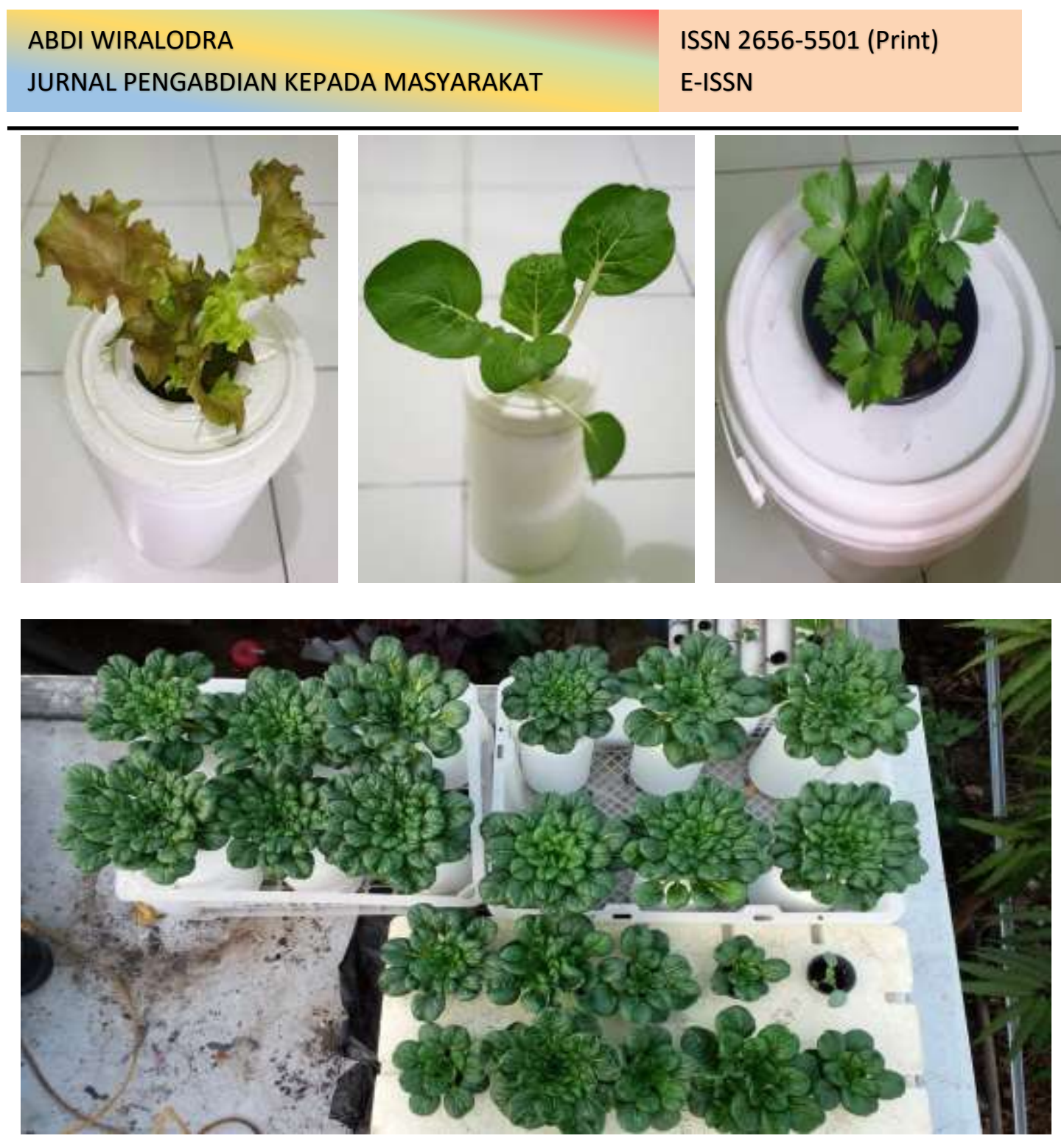

Gambar 7. Instalasi Hidroponik Wick System yang dibuat oleh peserta Pelatihan

Setelah dilaksanakan pelatihan tingkat dasar, pada tanggal 2 Maret 2018 dilakukan pelatihan tingkat lanjutan. Pelatihan tingkat lanjutan ini dilaksanakan dengan penyampaian teori dan praktek. Beberapa teori yang disampaikan dalam pelatihan adalah :

1. Meramu nutrisi hidroponik

Pada materi tentang pengetahuan dan keterampilan meramu nutrisi hidroponik disampaikan bahwa nutrisi adalah merupakan hal yang penting dilakukan, Sukses berusahatani hidroponik tergantung pada ramuan unsur hara atau nutrisi yang diberikan untuk tanaman. Ramuan nutrisi yang baik akan menghasilkan sayuran yang berkualitas baik dan nilai jualnyapun tinggi (Sutiyoso, 2003).

2. Persemaian dan penanaman

Pada materi tentang persemaian dan penanaman ini disampaikan pentingnya cara pemilihan benih yang baik, penyemaian benih yang baik sampai tanaman sayuran 


\section{ABDI WIRALODRA \\ ISSN 2656-5501 (Print) \\ JURNAL PENGABDIAN KEPADA MASYARAKAT \\ E-ISSN}

tersebut siap tanam. Pemahaman tentang persemaian dan penanaman ini penting karena sangat menentukan optimal tidaknya pertumbuhan tanaman, dengan penyemaian yang baik tumbuhan akan cepat beradaptasi, dan dalam penyemaian tersebut kita juga dapat menyortir tanaman yang baik dan siap untuk ditanam. Inti dari penyampaian materi ini adalah penyemaian dan penanaman adalah merupakan hal yang sangat perlu dilakukan agar tanaman tumbuh dengan optimal dan menghasilkan sayuran yang berkualitas.

3. Pemeliharaan

Pada penyampaian materi tentang pemeliharaan ini, peserta pelatihan diberikan pemahaman tentang pentingnya pemeliharaan tanaman sayuran dengan sistem hidroponik, materi yang disampaikan adalah : pengecekan kondisi air dalam penampungan dan pipa saluran air, pengecekan kepekatan nutrisi, menjaga kebersihan wadah tanaman, pengecekan kondisi tanaman, pengecekan media tanaman, sortasi tanaman yang tumbuh baik dan tidak baik.

4. Pengenalan sistem NTF dan DFT

Pada penyampaian materi tentang pengenalan sistem NTF dan DTF, peserta diberikan pengetahuan berupa keunggulan dan kelemahan serta keterampilan dalam penggunaan kedua sistem hidroponik ini.

Setelah dilakukan pelatihan persemaian dan meracik nutrisi, penanaman serta pemeliharaan dengan sistem NTF dan DFT, pada tanggal 4 April 2019 dilaksanakan pelatihan perlakuan pasca panen, setelah tanaman hidroponik berumur 25 hari setelah tanam. Peserta pelatihan diajarkan bagaimana cara memanen sayuran dan memperlakukan sayuran setelah di panen. Beberapa kegiatan pada pelatihan ini dapat dilihat pada Gambar 8. Berikut ini:
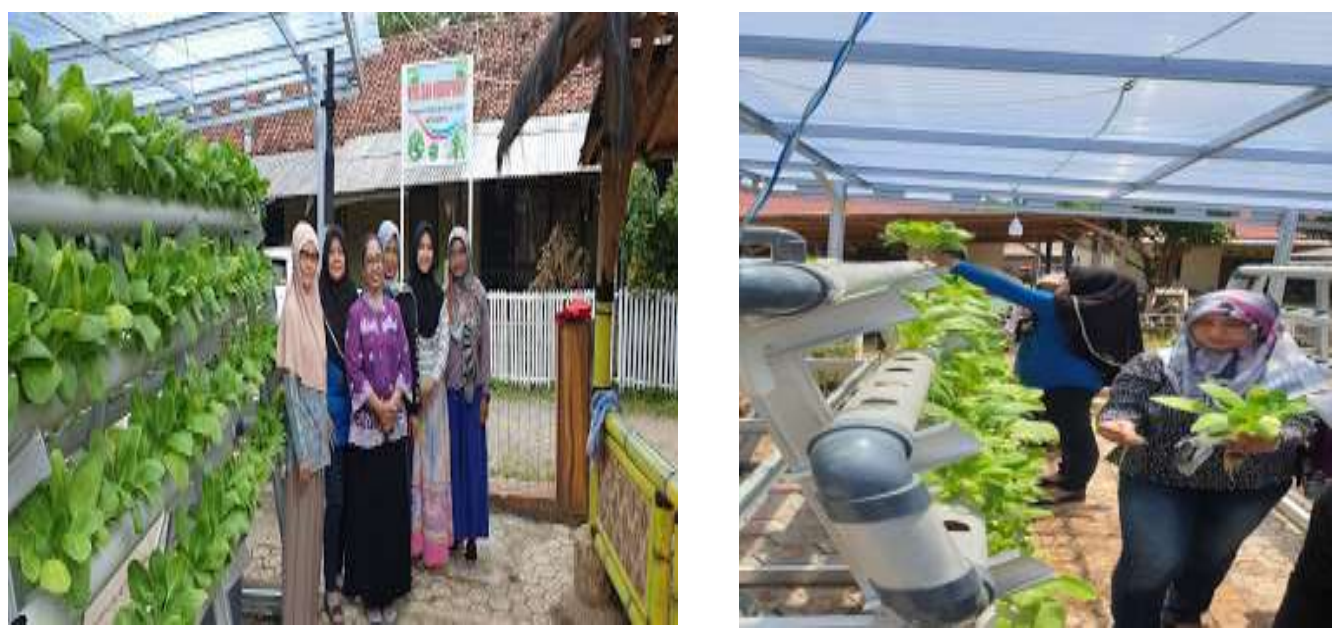

Universitas Wiralodra 

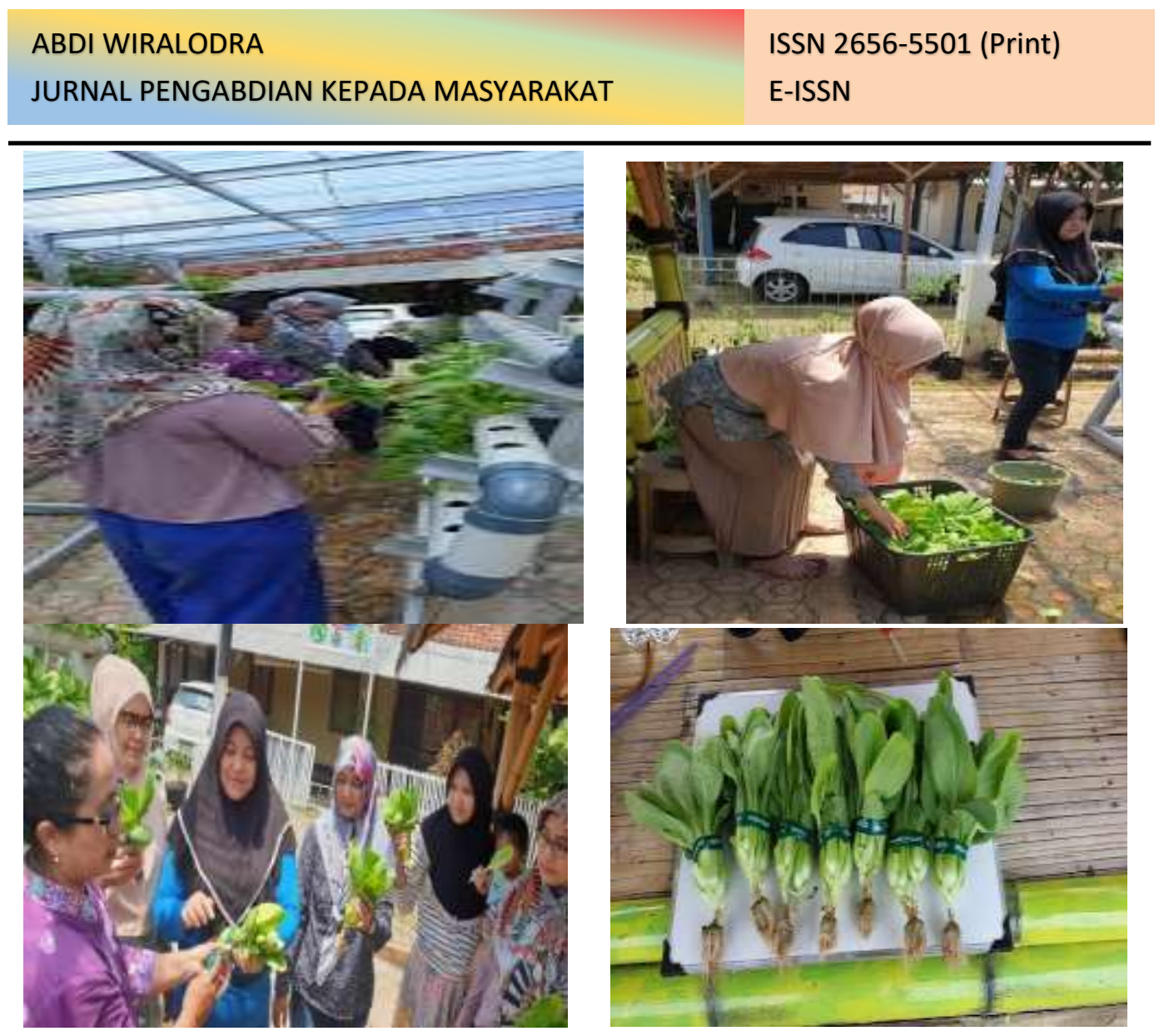

Gambar 8. Kegiatan Pelatihan Panen dan Pasca Panen

Berdasarkan gambar di atas, terlihat bahwa peserta pelatihan telah mempunyai pengetahuan dan mengatasi keterampilan dalam memanen perlakuan pasca panen sayuran hasil budidaya sistem hidroponik. Secara umum pelaksanaan pelatihan pada tahapan ini telah berhasil mendorong minat peserta pelatihan, akan tetapi masih terdapat beberapa kekurangan yaitu: 1) peserta pelatihan hanya memahami satu jenis sayuran saja yang di tanam yaitu tanaman pakcoy; 2) sayuran hasil budidaya sistem hidroponik hasil pelatihan belum sesuai dengan harapan, karena masih terlihat kekurangan unsur hara, hal tersebut diakibatkan karena masih lemahnya pemahaman peserta pelatihan tentang unsur hara tanaman (nutrisi hidroponik). Oleh karena itu perlu adanya pelatihan lanjutan tentang penanaman sayuran sistem hidroponik dengan berbagai tanaman sayuran yang berbeda serta pemahaman tentang kepekatan (EC) serta derajat keasaman nutrisi $\mathrm{pH}$ ).

Berdasarkan permasalahan yang dihadapi di atas, maka pada tanggal 26 Juni 2019, dilaksanakan pelatihan, Adapun tujuan pelatihan ini adalah memberikan pemahaman dan kerterampilan lanjutan kepada peserta pelatihan tentang budidaya tanaman sayuran dengan sistem hidroponik dengan beberapa tanaman sayuran yang berbeda, serta pemahaman tentang kepekatan (EC) serta derajat keasaman nutrisi $\mathrm{pH}$ ).

Pemahaman tentang dua hal tersebut di atas sangat penting karena semakin meningkatnya kesadaran masyarakat untuk mengkonsumsi berbagai macam sayuran sebagai sumber gizi keluarga serta peluang pasar masih sangat terbuka. sehingga 
membutuhkan pemahaman tentang budidaya hidroponik dengan beberapa sayuran yang berbeda. Selain itu konsumen juga lebih selektif dalam memilih barang yang akan dibelinya. Konsumen mempunyai kecenderungan memilih barang yang berkualitas sehingga seorang produsen harus memahami dan mempunyai keterampilan mengenai cara berproduksi yang baik.

Setelah dilakukan pelatihan, terlihat adanya peningkatan pengetahuan, sikap dan keterampilan peserta pelatihan, hal tersebut dapat dilihat dari adanya peningkatan mutu dan kualitas sayuran yang dihasilkan oleh peserta pelatihan. Sayuran yang dihasilkan lebih segar dan terlihat lebih hijau dibandingkan dengan hasil panen sebelummya. Sehinga dapat disimpulkan bahwa sayuran yang dihasilkan telah memenuhi standar dan siap dipasarkan.

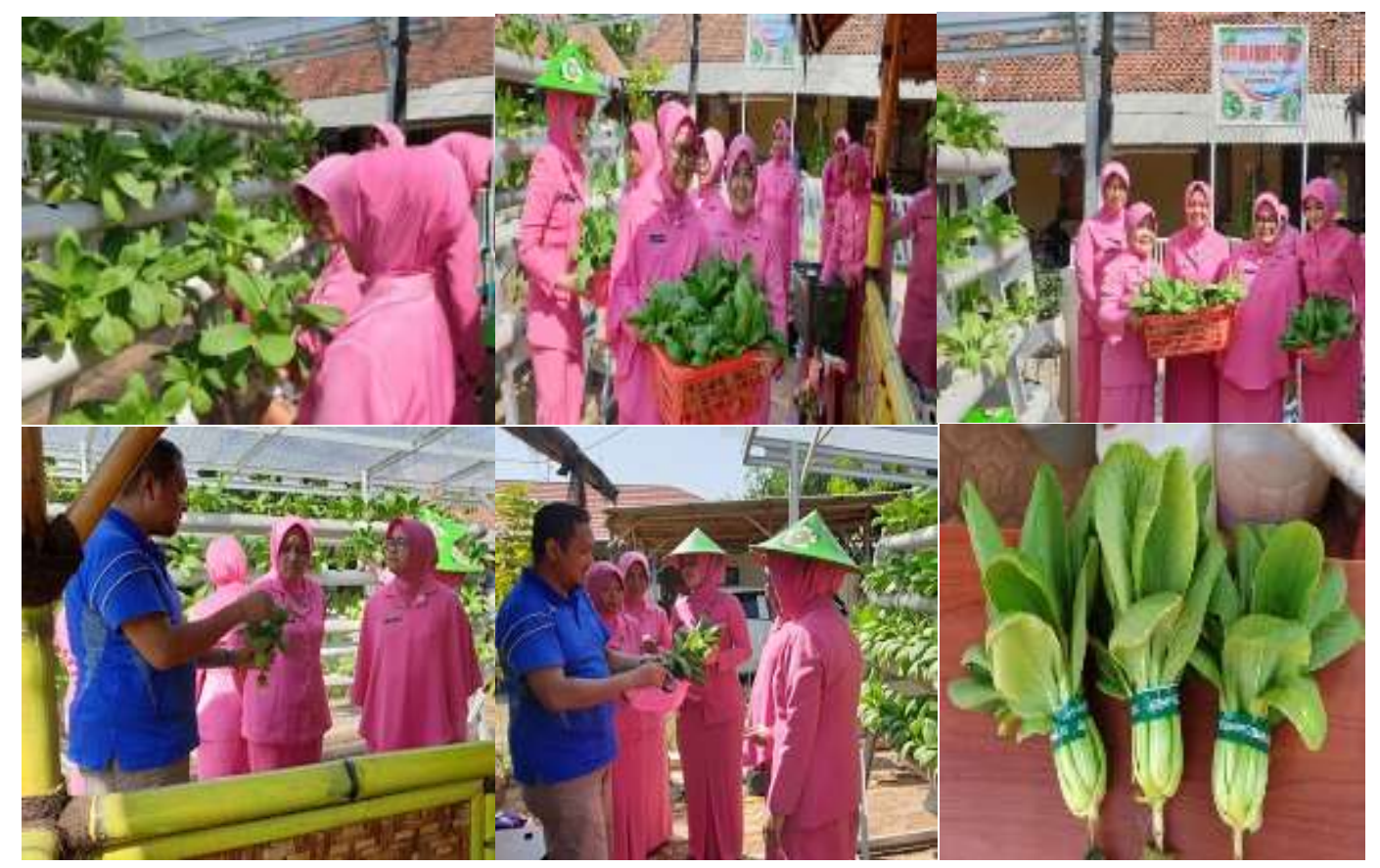

Gambar 9. Pelatihan Pemberian Label pada Sayuran Hidroponik

Pemahaman tentang ilmu pemasaran sayuran hidroponik sangat diperlukan sehingga peserta pelatihan harus memahami perlakuan konsumen sayuran hidroponik. Menurut Firmansyah (2018) perilaku konsumen adalah suatu proses yang berkaitan erat dengan adanya suatu proses pembelian, pada saat itu konsumen melakukan aktivitas seperti melakukan pencarian, penelitian dan pengevaluasian produk dan jasa (product and service). Perilaku konsumen merupakan sesuatu yang mendasari konsumen untuk mengambil keputusan dalam pembelian. Pengambilan keputusan tersebut berkaitan erat dengan kualitas produk, harga produk dan bagaimana mempromosikannya.

Berkaitan dengan hal tersebut maka pada tanggal 3 Agustus 2019 dilakukanlah pelatihan pemahaman tentang ilmu pemasaran sayuran hidroponik. Materi pelatihan 
yang disampaikan adalah bagaimana pengemasan produk yang sudah dihasilkan, bagaimana mempromosikan produk.

Pengemasan produk dilakukan dengan pemberian label fresh vegetables. Pemberian label pada produk adalah sebagai sumber informasi produk dan penjual, Tujuan utamanya adalah agar barang yang kita produksi menjadi lebih dikenal karena memberikan label berarti kita mengiklankan produk yang dihasilkan. Menurut Kotler (2000), label mempunyai beberapa fungsi, antara lain : 1) label mengidentifikasikan produk dan merk; 2) label membentuk kelas produk; 3. Label menggambarkan beberapa hal mengenai produk; 4) label dapat menjadi media promosi tentang produk.

Setelah Pemberian label tahapan yang sangat dibutuhkan dalam memasarkan produk adalah bagaimana mempromosikan produk yang telah dihasilkan. Pada pelatihan disampaikan beberapa hal yang berkaitan dengan promosi produk, yaitu; 1) pemanfaatkan media sosial yaitu melalui facebook, twitter, instagram maupun whatsaap; 2) memanfaatkan komunitas yaitu komunitas pengajian, arisan; 3) membuat brosur maupun papan reklame tentang produk yang dihasilkan.

Berdasarkan beberapa pelatihan tahapan yang telah dilakukan dari awal sampai kegiatan pelatihan berakhir kegiatan, peserta pelatihan telah mempunyai pengetahuan, sikap dan keterampilan dalam budidaya tanaman sayuran dengan sistem hidroponik. Hal tersebut terlihat dengan berhasilnya peserta pelatihan menghasilkan produk berupa sayuran hidroponik dengan kualitas yang baik. Akan tetapi yang harus terus dilakukan adalah upaya pembinaan yang terus- menerus agar peserta pelatihan mau dan mampu menerapkan ilmu yang diperolehnya.

Apabila pembinaan pengembangan budidaya tanaman sayuran dengan sistem hidroponik dilakukan secara terus-menerus, maka bukan hanya memberdayakan rumah tangga dan masyarakat dalam penyediaan sumber pangan dan gizi melalui optimalisasi pemanfaatan pekarangan dan lahan sekitar tempat tinggal saja, akan tetapi ada hal lain yang bisa diperoleh yaitu kegiatan tersebut dapat meningkatkan kualitas lingkungan dan memperluas kesempatan peningkatan perekonomian karena sayuran yang berasal dari budidaya sistem hidroponik mempunyai nilai jual yang tinggi.

Pengembangan Kawasan Rumah Pangan Lestari (KRPL) melalui budidaya tanaman sayuran sistem hidroponik di KRPL Bhayangkari Cabang Indramayu telah sukses dilaksanakan dan telah memberikan pengetahuan dan keterampilan, akan tetapi ada beberapa hal yang harus diperhatikan yaitu : 1) pelatihan dan pembinaannya harus terus dilakukan oleh pengurus Bahayangkari Cabang Indramayu bersama Fakultas Pertanian Universitas Wiralodra agar tercipta KRPL di lingkungan peserta pelatihan dan menumbuhkan sikap dan tanggung jawab dan meningkatkan kesadaran untuk berpartisipasi dalam penyediaan sumber pangan dan gizi keluarga dan tumbuhnya kesadaran tentang pemeliharaan lingkungan; 2) perlu adanya peningkatan pemahaman mengenai potensi pemanfaatan lingkungan yang dalam meningkatkan perekonomian keluarga dengan meningkatkan mutu pelatihan yang menitik beratkan pada pemanfaatan peluang pasar dan aspek pemasaran sayuran hidroponik. 


\section{Simpulan dan saran}

\section{Simpulan :}

Berdasarkan uraian tentang pelaksanaan pelatihan dan pengembangan dudidaya tanaman dengan sistem hidroponik yang telah dilaksanakan oleh pengurus Bhayangkari Cabang Indramayu bekerjasama dengan Fakultas Pertanian Indramayu, maka diperoleh beberapa kesimpulan sebagai berikut :

a. Setelah dilakukan pelatihan, peserta pelatihan mempunyai keterampilan dalam membudidayakan sayuran dengan sistem hidroponik dengan berbagai metode yaitu wick system, NFT Sistem (Nutrient Film Technique) dan DFT Sistem (Deep Flow Technique).

b. Setelah dilakukan pelatihan, peserta pelatihan memahami penanganan sayuran setelah panen dan memahami bagaimana strategi yang harus dilakuakan dalam memasaran sayuran sistem hidroponik.

\section{S a r a n :}

Terdapat beberapa saran berkaitan dengan pelaksanaan pelatihan dan pengembangan budidaya tanaman dengan sitem hidroponik yang telah yaitu:

a. Pelatihan budidaya sistem hidroponik yang telah dilaksanakan sebaiknya diimplementsikan dalam rangka melaksanakan gaya hidup sehat dengan pola gizi seimbang sesuai dengan Program "GERMAS" (Gerakan Masyarakat Sehat) sebagai upaya pencegahan terhadap gangguan kesehatan keluarga dengan memanfaatlkan lahan pekarangan dengan menggunakan sistem hidroponik.

b. Penerapan hasil pelatihan budidaya sistem hidroponik yang telah dilakukan sebaiknya bukan hanya untuk memenuhi kegutuhan gizi keluarga saja akan tetapi dijadikan sebagai kegiatan yang bermanfaat dalam perekonomian yang bisa meningkatkan taraf hidup.

c. Perlu adanya pelatiahan dan pembinaan yang berkesinambungan dengan meningkatkan mutu pelatihan yang menitik beratkan pada pemanfaatan peluang pasar dan aspek pemasaran sayuran hidroponik

\section{Daftar Pustaka}

Firmansyah, A. 2018. Perilaku Konsumen (Sikap Pemasaran). Deepublish. Yogyakarta

https://id.pinterest.com/pin/591378994788675315/ (diakses pada tanggal 13 September 2019)

http://www.yoonhidroponik.web.id/2017/07/hydroponics-deep-flow-techniquesystem.html, (diakses pada tanggal 13 September 2019

Kementerian Pertanian Republik Indonesia. 2018 . Petunjuk Teknis Optimalisasi Pemanfaatan Lahan Pekarangan Melalui Kawasan Rumah Pangan Lestari $(K R P L) . K e m e n t e r i a n$ Pertanian Indonesia. Jakarta 


\section{ABDI WIRALODRA}

\section{JURNAL PENGABDIAN KEPADA MASYARAKAT}

Kementrian Hukum dan Hak Asasi Manusia Republik Indonesia. 2012. Undangundang Republik Indonesia nomor 18 tahun 2012, tentang Pangan. Jakarta.

Kotler, P., Keller, K.L. 2006. Marketing Management. _Upper Saddle, New Jersey.

Soekartawi. 2005. Prinsip Dasar Komunikasi Pertanian. UI Press. Jakarta

Sutiyoso, Y. 2003. Meramu Pupuk Hidroponik Tanaman Sayur, Tanaman Buah, Tanaman Bunga. Penebar Swadaya. Jakarta. 